\title{
Age-related changes in corneal thickness and endothelial characteristics
}

This article was published in the following Dove Press journal:

Clinical Interventions in Aging

23 October 2013

Number of times this article has been viewed

\section{Saulius Galgauskas \\ Dovilè Norvydaitè \\ Dalia Krasauskaitè \\ Simona Stech \\ Rimvydas Stanislovas \\ Ašoklis}

Vilnius University Faculty of Medicine, ENT and Eye Diseases Clinic, Vilnius University Hospital Santariskiu Clinic, Center of Eye Diseases, Vilnius, Lithuania

Correspondence: Saulius Galgauskas Vilnius University Faculty of Medicine, Vilnius University Hospital Santariskiu Clinic, Center of Eye Diseases, Santariskiu 2, 0866I, Vilnius, Lithuania Tel +37068726238

Email saulius.galgauskas@santa.It
Purpose: To determine the influence of age on central corneal thickness (CCT), endothelial cell density (ECD), average cell size, coefficient of variation in cell size, and percentage of regular hexagonal cells; and to estimate the average ECD and CCT in seven age groups.

Materials and methods: After obtaining informed consent, 211 Caucasian patients (358 eyes) were examined using a noncontact specular microscope at the Center of Eye Diseases in Vilnius University Hospital Santariskiu Clinic. The main corneal parameters were: ECD, average cell size, coefficient of variation in cell size, percentage of regular hexagonal cells, and CCT. Subjects (20-89 years) were stratified by age into seven groups. Correlations between CCT, endothelial parameters (ECD, percentage of regular hexagonal cells, average, coefficient of variation), and age were found. Student's $t$-test and Pearson's correlation coefficient ( $r$ ) values were calculated.

Results: A total of 114 (54.03\%) women and 97 (45.97\%) men participated in the study. Average ECD $\left(\right.$ cell $\left./ \mathrm{mm}^{2}\right)$ ranged from 2,931 $( \pm 371)$ in 20-29 year olds to 2,222 $( \pm 182)$ in 80-89 year olds; CCT $(\mu \mathrm{m})$ ranged from $563( \pm 44)$ in $20-29$ year olds to $540( \pm 35)$ in $80-89$ year olds. A strong inverse correlation was observed between age and corneal ECD $(r=-0.650, P<0.01)$ and a weak inverse correlation was observed between age and CCT $(r=-0.156, P<0.01)$. ECD and CCT correlated directly $(r=0.232, P<0.01)$. The average size of corneal endothelial cells directly correlated with age $(r=0.586, P<0.01)$. There was no correlation between age and the coefficient of variation in cell size nor the percentage of regular hexagonal cells $(P>0.05)$.

Conclusion: Young people have higher ECD. CCT also decreases, but its dependence on age is weaker. A lower cell density indicates a thinner cornea. The variation in cell size and percentage of regular hexagonal cells are not dependent on age.

Keywords: cornea, endothelium, age-related changes

\section{Introduction}

The measurement of central corneal thickness (CCT) and endothelial cell density (ECD) is important for evaluating endothelial function for diagnostic purposes or before various surgical interventions.

The endothelium is one of the five layers of the cornea and it covers the posterior surface. These metabolically active cells are responsible for regulating fluid and solute transport between the aqueous and corneal stromal compartments. Only adequately hydrated stroma maintains corneal transparency. Knowing the function of corneal endothelium allows assessment of the donor corneas, and the risk and effect of intraocular and corneal procedures in clinical practice. Like every tissue of the human body, the cornea undergoes age-associated changes. Corneal endothelial 
cells' repair capacity is very limited. ${ }^{1}$ The lack of cell proliferation determinates age-related reduction of ECD. As the endothelial cell count decreases, the remaining cells enlarge and cover the gaps. ${ }^{2}$ As a result of aging, endothelial pump function deteriorates, wound healing slows down, and the results of refractive surgery become poor. ${ }^{3}$ It should be remembered that the value of intraocular pressure depends on corneal thickness: a thick cornea is a reason for falsely high measurements of intraocular pressure and, conversely, falsely low measurements of intraocular pressure occurs in thin corneas. ${ }^{4}$ This should be taken into consideration, especially when examining the elderly, which is the main group of glaucoma patients.

Standards must be established in order to compare the results of different groups. Endothelial parameters and CCT vary in each population..$^{5-7}$ Therefore, it is very important to verify the results and determine the limits of normal values. Furthermore, corneal parameters differ between subjects grouped by age. ${ }^{5,7-16}$ Understanding these ethnicand age-related physiological changes in human tissues enables assessment of the influence of diseases and surgical procedures.

The purpose of this study was to compare CCT and endothelial cell parameters between subjects in different age groups and identify correlations between them.

\section{Materials and methods}

After obtaining informed consent, 211 patients (358 eyes) were examined using a noncontact specular microscope (Konan Noncon Specularmicroscope V, SP-9000; Konan Medical Inc., Hyogo, Japan) at the Center of Eye Diseases in Vilnius University Hospital Santariskiu Clinic from 4-6 PM. The main corneal parameters were: ECD, mean size of cells (Ave), coefficient of variation in average cell size $(\mathrm{CV})$, percentage of regular hexagonal cells (A6), and CCT. Patients' age and sex were also noted. All the patients were Caucasians of Lithuanian origin. Exclusion criteria were: glaucoma, diabetes mellitus, corneal degeneration, keratitis, conjunctivitis, ulcers, traumatic lesions, corneal transplantation, and other anterior segment surgical procedures. The age of all subjects ranged from 20-89 years, and subjects were allocated into seven groups stratified by age. Each group included a 10-year interval: 20-29 years (55 eyes, 28 patients), 30-39 years ( 45 eyes, 26 patients), 40-49 years ( 45 eyes, 29 patients), $50-59$ years ( 55 eyes, 31 patients), 60-69 years ( 55 eyes, 34 patients), $70-79$ years ( 55 eyes, 33 patients), and 80-89 years ( 48 eyes, 30 patients). The number of men and women in each group was nearly equal. The average ECD and CCT were calculated and results were compared
Table I The average subjects' age in each group

\begin{tabular}{lllll}
\hline $\begin{array}{l}\text { Age } \\
\text { (years) }\end{array}$ & $\begin{array}{l}\text { Minimal } \\
\text { value }\end{array}$ & $\begin{array}{l}\text { Maximal } \\
\text { value }\end{array}$ & Average & $\begin{array}{l}\text { Standard } \\
\text { deviation }\end{array}$ \\
\hline $20-29$ & 20 & 28 & 23 & 1 \\
$30-39$ & 30 & 39 & 34 & 3 \\
$40-49$ & 40 & 49 & 46 & 3 \\
$50-59$ & 50 & 59 & 54 & 3 \\
$60-69$ & 60 & 69 & 65 & 2 \\
$70-79$ & 70 & 79 & 76 & 3 \\
$80-89$ & 80 & 89 & 84 & 3 \\
\hline
\end{tabular}

between the groups. Correlations between CCT, endothelial parameters (ECD, A6, Ave, and CV), and age were found. IBM SPSS $^{\circledR} 20.0$ (IBM Corporation, Armonk, NY, USA) and Microsoft Excel ${ }^{\circledR} 2007$ (Microsoft Corporation, Redmond, WA, USA) were used for statistical analysis. Student's $t$-test and Pearson's correlation coefficient $(r)$ values were calculated. Data were considered statistically significant when $P<0.05$.

\section{Results}

A total of 114 (54.03\%) women and 97 (45.97\%) men participated in the study. Table 1 shows the average subjects' age in each group. The average ECD (cells $\left./ \mathrm{mm}^{2}\right)$ is presented in Table 2 and CCT $(\mu \mathrm{m})$ is presented in Table 3. No statistically significant difference was found between the sexes $(P>0.05)$. A strong inverse correlation was observed between age and ECD $(r=-0.650, P<0.01)$, which means that ECD decreases over a lifetime (Figure 1). A weak inverse correlation was found between age and CCT $(r=-0.156$, $P<0.01$ ) (Figure 2). CCT also decreased with age, but the correlation was weaker. ECD and CCT correlated directly $(r=0.232, P<0.01)$, linking high ECD with thick corneas. While there was a direct correlation between Ave and age $(r=0.586, P<0.01)$ (Figure 3), CV did not show such reliance on aging (Figure 4). Age and A6 did not correlate either $(P>0.05)$ (Figure 5). Taking everything into account, ECD

Table 2 The average endothelial cell density (cells $/ \mathrm{mm}^{2}$ ) in each group

\begin{tabular}{llllll}
\hline $\begin{array}{l}\text { Age } \\
\text { (years) }\end{array}$ & $\begin{array}{l}\text { Number } \\
\text { of eyes } \\
\text { examined }\end{array}$ & $\begin{array}{l}\text { Minimal } \\
\text { value }\end{array}$ & $\begin{array}{l}\text { Maximal } \\
\text { value }\end{array}$ & Average & $\begin{array}{l}\text { Standard } \\
\text { deviation }\end{array}$ \\
\hline $20-29$ & 55 & 2,232 & 3,610 & 2,931 & 371 \\
$30-39$ & 45 & 2,353 & 3,279 & 2,820 & 203 \\
$40-49$ & 45 & 2,160 & 3,546 & 2,660 & 301 \\
$50-59$ & 55 & 2,062 & 3,571 & 2,630 & 306 \\
$60-69$ & 55 & 2,015 & 3,003 & 2,518 & 281 \\
$70-79$ & 55 & 2,062 & 2,762 & 2,341 & 167 \\
$80-89$ & 48 & 2,002 & 2,597 & 2,222 & 182 \\
\hline
\end{tabular}


Table 3 The average central corneal thickness $(\mu \mathrm{m})$ in each group

\begin{tabular}{llllll}
\hline $\begin{array}{l}\text { Age } \\
\text { (years) }\end{array}$ & $\begin{array}{l}\text { Number } \\
\text { of eyes } \\
\text { examined }\end{array}$ & $\begin{array}{l}\text { Minimal } \\
\text { value }\end{array}$ & $\begin{array}{l}\text { Maximal } \\
\text { value }\end{array}$ & Average & $\begin{array}{l}\text { Standard } \\
\text { deviation }\end{array}$ \\
\hline $20-29$ & 55 & 474 & 646 & 563 & 44 \\
$30-39$ & 45 & 477 & 640 & 561 & 36 \\
$40-49$ & 45 & 494 & 681 & 559 & 42 \\
$50-59$ & 55 & 459 & 647 & 553 & 43 \\
$60-69$ & 55 & 495 & 630 & 555 & 35 \\
$70-79$ & 55 & 448 & 672 & 551 & 46 \\
$80-89$ & 48 & 430 & 637 & 540 & 35 \\
\hline
\end{tabular}

and CCT decreased and Ave rose, whereas CV and A6 were not dependent on age.

\section{Discussion}

This study has shown that ECD and CCT decrease with age. The loss of endothelial cells is greater than the decrease in corneal thickness over the years, but the tendency of fewer endothelial cells in thin corneas remains. Older people usually have thinner corneas.

Some scientists examined corneal endothelium and found that ECD decreases with age., ${ }^{5,12-14}$ In 2007, a Portuguese study estimated that ECD decreases 5\%-6\% every 10 years. ${ }^{14}$ Similar results were obtained in other countries: Denmark revealed an ECD reduction of $0.3 \%$ every year and New Zealand demonstrated a $0.5 \%$ reduction. ${ }^{15,16}$ Cheng et al found a loss of endothelial cells reaching $1 \%$ every year. ${ }^{17}$ The risk for ECD to decrease to 2,000 cell $/ \mathrm{mm}^{2}$ (the limit at which endothelium can no longer ensure its normal function) rises in a population $>70$ years of age. ${ }^{12}$ Data show that young and healthy Lithuanians have higher ECD compared to older people and those with cataracts or glaucoma. ${ }^{18}$ Recent studies confirmed a relationship between CCT and age, ie, the human cornea becomes thinner with age. ${ }^{7-11}$ It was found that CCT declines about $4 \mu \mathrm{m}$ (in male corneas) to $5 \mu \mathrm{m}$ (in female corneas) every 10 years. ${ }^{11}$ A previous investigation of a Lithuanian population in 2010 revealed that CCT decreases gradually when people reach the age of 40 years. ${ }^{4}$ However, some studies have not found the same dependence. ${ }^{16,19,20}$

A control group that the authors examined could be used to analyze and compare various data, including eye or systemic pathologic conditions. Although the results are heterogeneous, diseases possibly influence the cornea. ${ }^{21-23}$ This risk was minimized by examining only healthy people. Primary arterial hypertension was an exception. Patients with primary arterial hypertension were included because no evidence of its impact on the corneal endothelium has been found. Furthermore, $50.8 \%$ of people $>65$ years old who live in Vilnius suffer from primary arterial hypertension. ${ }^{24}$ Endothelial cells are not only affected by disease - intraocular surgical procedures have the greatest impact. ${ }^{25,26}$ The decline in ECD increases the risk of developing glaucoma or corneal graft failure. ${ }^{27}$

The number of men and women in this study was nearly equal (97 and 114 subjects, respectively). This allowed assessment of the influence of sex on the corneal endothelium cell parameters. Such influence is still being debated. Although no relationship was observed in this study, Snellingen et al in South Asia found that ECD is $2.9 \%$ higher in women than in men. ${ }^{6}$ Another study reported that men's endothelial cells are more regular, ie, the endothelium has more hexagonal cells. ${ }^{18}$ A significant difference in CCT between the sexes was

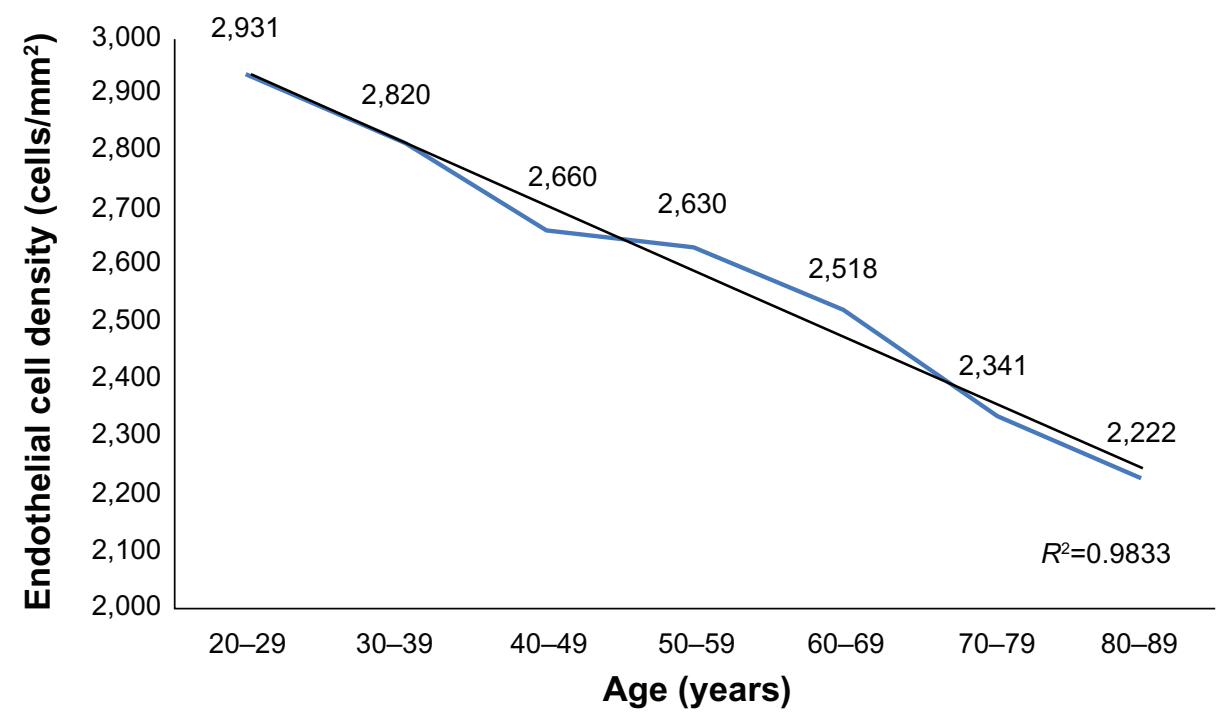

Figure I The change in endothelial cell density across age groups. 


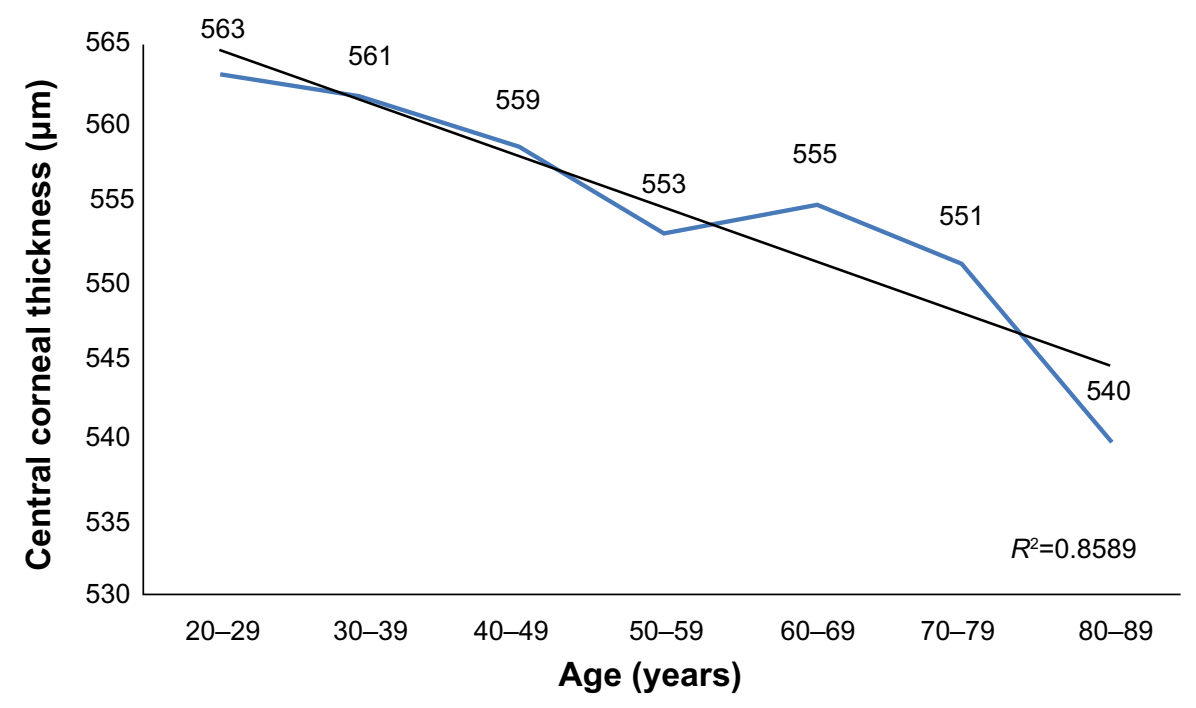

Figure 2 The change in central corneal thickness across age groups.

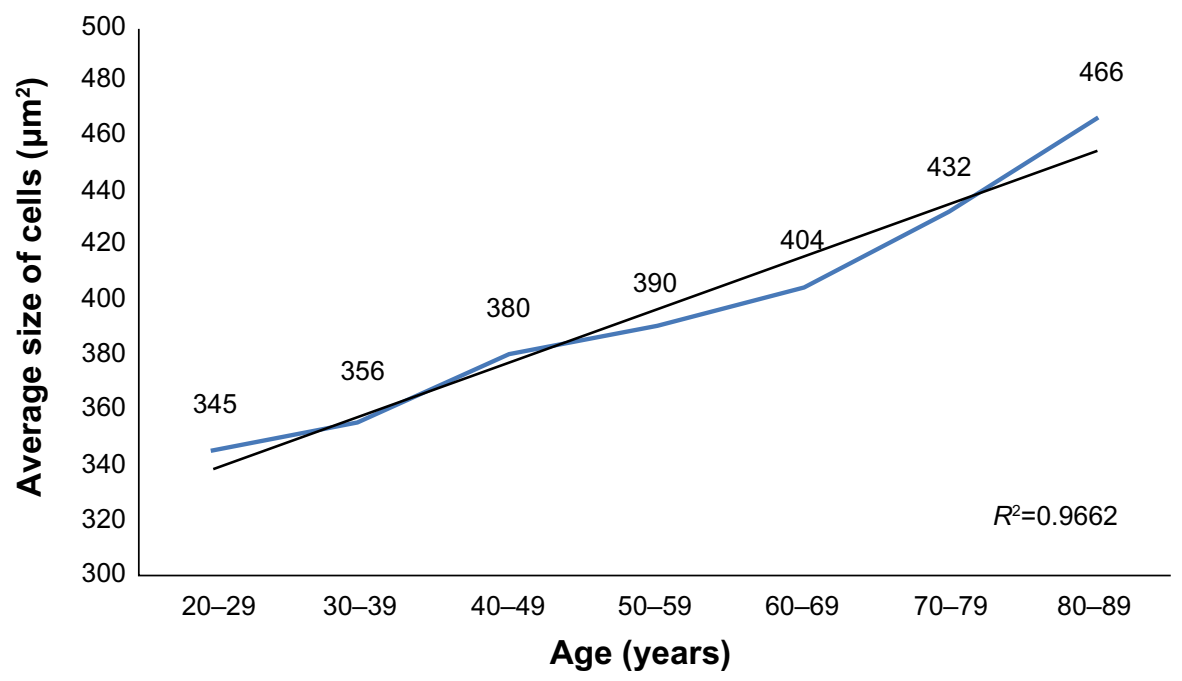

Figure 3 The change in average cell size across age groups.

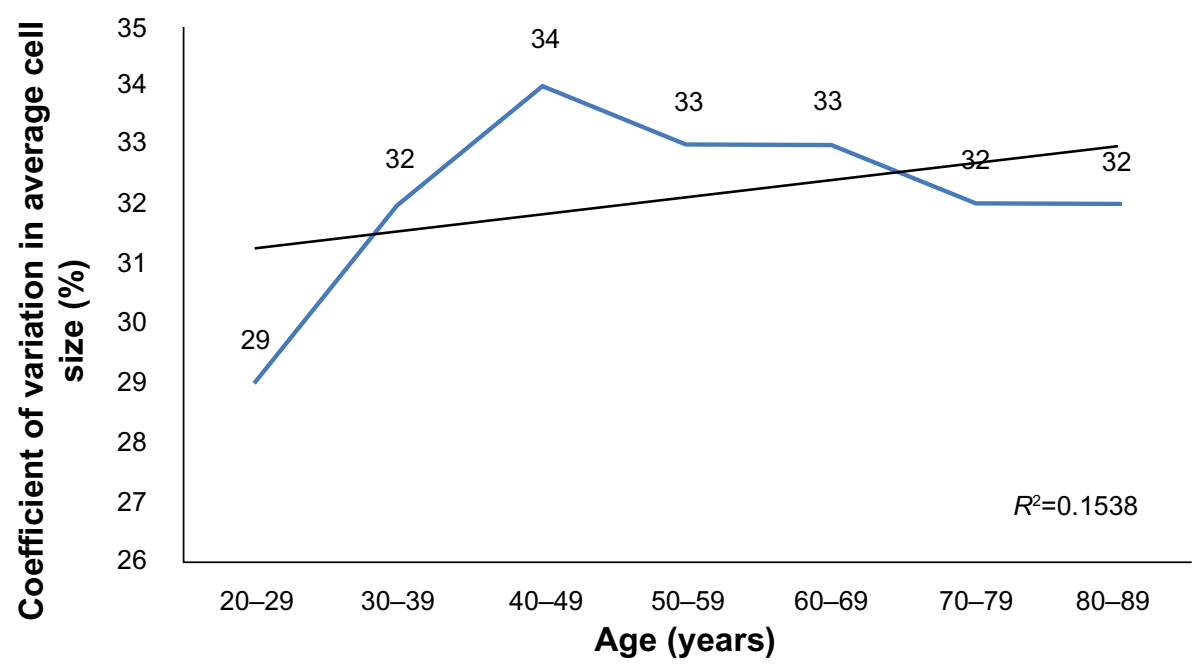

Figure 4 The change in the coefficient of variation in average cell size across age groups. 


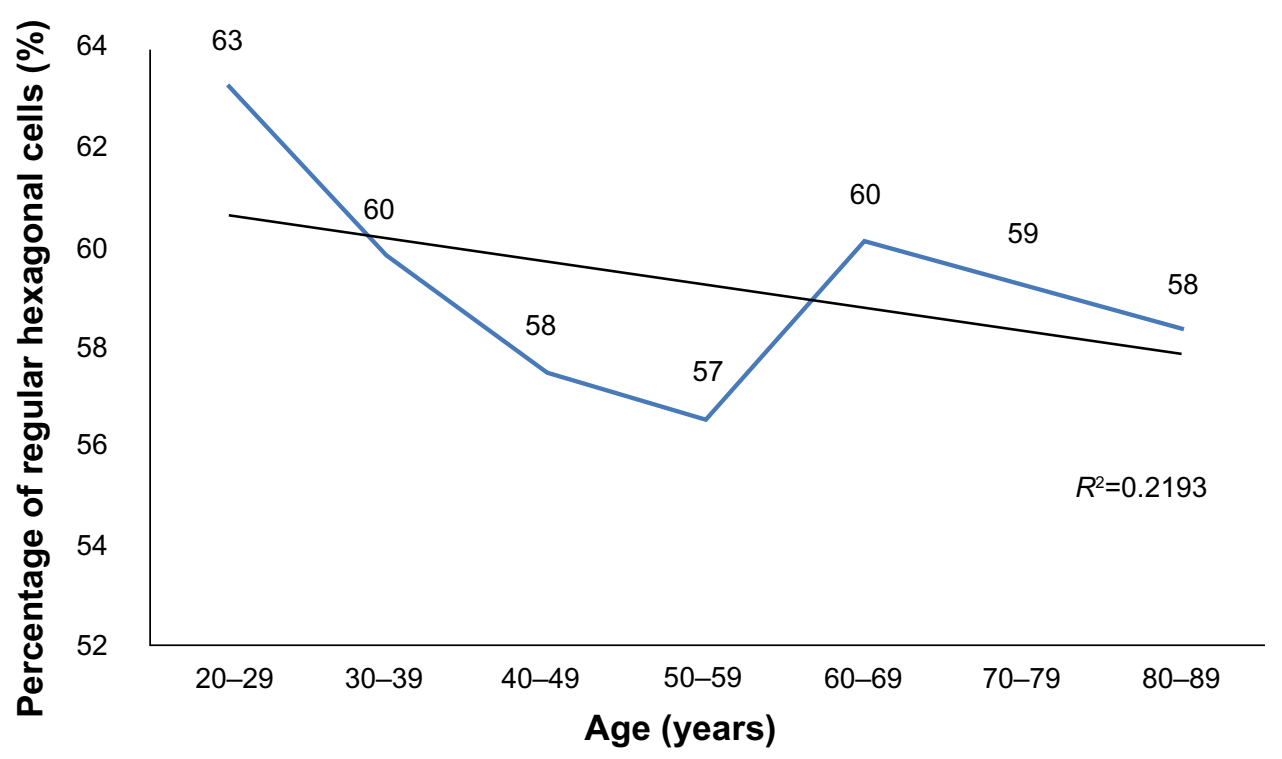

Figure $\mathbf{5}$ The change in the percentage of regular hexagonal cells across age groups.

not demonstrated. ${ }^{28}$ These findings imply that the influence of sex on endothelial parameters is still unknown and more studies are required.

A similar number of subjects in each decade (45-55 eyes) enabled identification of the critical age periods at which endothelium changes. Interestingly, the greatest ECD decline is observed in neonates and children - Moller-Pedersen demonstrated a $2.9 \%$ decline over a year. ${ }^{15}$ As the present study was carried out in an adult clinic, there was no opportunity to examine children.

ECD and corneal thickness were measured only in the center of the cornea. Both ECD and corneal thickness are lower in the central part than in the periphery of the cornea. ${ }^{29-31}$ Subtle changes in the central cornea lead to greater clinical significance. CCT varies over the day. The cornea is thickest in the morning and gradually becomes thinner. ${ }^{32-34}$ To reduce errors, CCT and ECD were measured at the same time of day (4-6 PM).

The regeneration of the corneal endothelial cells is very weak. Cells are lost in a lifetime and new cells do not arise to replace them. The only way to ensure the integrity of the endothelium is to let old cells grow and fill in the gaps. The present data confirm results that show a positive correlation between age and Ave. Jorge et al reported that Ave

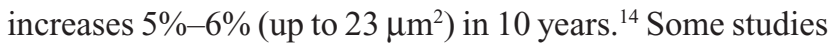
revealed that $\mathrm{CV}$ also correlates with age and increases over a lifetime, meaning that older people have more variation in cell size..$^{5,14,27}$ In addition, a negative correlation was found between A6 and age. ${ }^{5,14,24}$ In summary, healthy cells expand to cover the emerging endothelium defect, ECD decreases with age, and - according to some specialists - these large-sized cells become more irregular in their size and shape.

As a population gets older, the number of irreversible corneal endothelium lesions increases. Since not all patients who need corneal endothelium transplantation can be operated on due to a lack of donor tissues, experiments on transplantation of cultured human corneal endothelial cells sheets are being carried out. ${ }^{35}$

\section{Conclusion}

There are statistically significant differences in corneal parameters between people of different ages. Young Lithuanian subjects have thicker corneas, higher ECD, and smaller endothelial cells. CCT has a weaker connection with aging than ECD. A lower ECD indicates a thinner cornea. CV and A6 are not dependent on age.

\section{Disclosure}

The authors report no conflicts of interest in this work.

\section{References}

1. Ko MK, Park WK, Lee JH, Chi JG. A histomorphometric study of corneal endothelial cells in normal human fetuses. Exp Eye Res. 2001;72(4): 403-409.

2. Ayala G, Diaz ME, Martinez-Costa L. Granulometric moments and corneal endothelium status. Pattern Recognit. 2001;34:1219-1227.

3. Dutt S, Steinert RF, Raizman MB, Puliafito CA. One-year results of excimer laser photorefractive keratectomy for low to moderate myopia. Arch Ophthalmol. 1994;112(11):1427-1436.

4. Galgauskas S, Ringailaitė E, Juodkaitė G. [Central corneal thickness and its relationship to gender, intraocular pressure and corneal curvature]. Medicinos Teorija ir Praktika. 2009;15(1):19-23. Lithuanian [with English abstract]. 
5. Rao SK, Ranjan Sen P, Fogla R, Gangadharan S, Padmanabhan P, Badrinath SS. Corneal endothelial cell density and morphology in normal Indian eyes. Cornea. 2000;19(6):820-823.

6. Snellingen T, Rao GN, Shrestha JK, Huq F, Cheng H. Quantitative and morphological characteristics of the human corneal endothelium in relation to age, gender, and ethnicity in cataract populations of South Asia. Cornea. 2001;20(1):55-58.

7. Nemesure B, Wu SY, Hennis A, Leske C. Corneal thickness and intraocular pressure in the Barbados eye studies. Arch Ophthalmol. 2003;121(2):240-244.

8. Rufer F, Schroder A, Bader C, Erb C. Age-related changes in central and peripheral corneal thickness: determination of normal values with the Orbscan II topography system. Cornea. 2007;26(1):1-5.

9. Lekskul M, Aimpun P, Nawanopparatskul B, et al. The correlations between central corneal thickness and age, gender, intraocular pressure and refractive error of aged 12-60 years old in rural Thai community. J Med Assoc Thai. 2005;88(Suppl 3):S175-S179.

10. Galgauskas S, Garlaitė O, Juodkaitė G, Tutkuvienè J. [The mean central corneal thickness of the Lithuanian population]. Medicinos Teorija ir Praktika. 2010;16(1):15-20. Lithuanian [with English abstract].

11. Foster PJ, Baasanhu J, Alsbirk PH, Munkhbayar D, Uranchimeg D, Johnson GJ. Central corneal thickness and intraocular pressure in a Mongolian population. Ophthalmology. 1998;105(6):969-973.

12. Abib FC, Barreto J. Behavior of corneal endothelial density over a lifetime. J Cataract Refract Surg. 2001;27(10):1574-1578.

13. Sanchis-Gimeno JA, Lleo-Perez A, Alonso L, Rahhal MS, Martinez Soriano F. Corneal endothelial cell density decreases with age in emmetropic eyes. Histol Histopathol. 2005;20(2):423-427.

14. Jorge J, Queiros A, Peixoto-de-Matos SC, Ferrer-Blasco T, GonzalezMeijome JM. Age-related changes of corneal endothelium in normal eyes with a non-contact specular microscope. Journal of Emmetropia. 2010;1(2):132-139.

15. Moller-Pedersen T. A comparative study of human corneal keratocyte and endothelial cell density during aging. Cornea. 1997;16:333-338.

16. Niederer RL, Perumal D, Sherwin T, McGhee CN. Age-related differences in the normal human cornea: a laser scanning in vivo confocal microscopy study. Br J Ophthalmol. 2007;91(9):1165-1169.

17. Cheng H, Jacobs PM, McPherson K, Noble MJ. Precision of cell density estimates and endothelial cell loss with age. Arch Ophthalmol. 1985;103(10):1478-1481.

18. Galgauskas S, Krasauskaite D, Pajaujis M, Juodkaitė G, Asoklis RS. Central corneal thickness and corneal endothelial characteristics in healthy, cataract, and glaucoma patients. Clin Ophthalmol. 2012;6: 1195-1199.

19. Prasad A, Fry K, Hersh PS. Relationship of age and refraction to central corneal thickness. Cornea. 2011;30(5):553-555.
20. Kamiya K, Shimizu K, Ohmoto F, et al. Effect of aging on corneal biomechanical parameters using the ocular response analyzer. J Refract Surg. 2009;25(10):888-893.

21. Busted N, Olsen T, Schmitz O. Clinical observations on the corneal thickness and the corneal endothelium in diabetes mellitus. $\mathrm{Br} J$ Ophthalmol. 1981;65(10):687-690.

22. Liu Z, Pflugfelder S. Corneal thickness is reduced in dry eye. Cornea. 1999;18(4):403-407.

23. Singh RP, Goldberg I, Graham SL, Sharma A, Mohsin M. Central corneal thickness, tonometry, and ocular dimensions in glaucoma and ocular hypertension. J Glaucoma. 2001;10(3):206-210.

24. Arterinè hipertenzija - uždelsto veikimo bomba [Arterial hypertensiondelayed action bomb] [webpage on the Internet]. Vilnius: Vilnius Public Health Office; 2012 [cited May 17, 2012]. Available from: http://www. vvsb.lt/index.php/naujienos/343-arterin-hipertenzija-udelsto-veikimobomba. Accessed September 28, 2013. Lithuanian.

25. Edelhauser HF, Sanders DR, Azar R, Lamielle H. Corneal endothelial assessment after ICL implantation. J Cataract Refract Surg. 2004;30(3): $576-583$.

26. Ing JJ, Ing HH, Nelson LR, Hodge DO, Bourne WM. Ten-year postoperative results of penetrating keratoplasty. Ophthalmology. 1998;105(10): 1855-1865

27. Yunliang S, Yuqiang H, Ying-Peng L, Ming-Zhi Z, Lam DS, Rao SK. Corneal endothelial cell density and morphology in healthy Chinese eyes. Cornea. 2007;26(2):130-132.

28. Muller A, Craig JP, Grupcheva CN, McGhee CN. The effects of corneal parameters on the assessment of endothelial cell density in the elderly eye. Br J Ophthalmol. 2004;88(3):325-330.

29. Chuckpaiwong V, Holley GP, Parikh CH, Song DC, Edelhauser HF. Morphologic study of the far peripheral corneal endothelium in the human and rabbit [abstract]. Invest Ophthalmol Vis Sci. 2003;44:4722.

30. Amann J, Holley GP, Lee SB, Edelhauser HF. Increased endothelial cell density in the paracentral and peripheral regions of the human cornea. Am J Ophthalmol. 2003;135(5):584-590.

31. Martola EL, Baum JL. Central and peripheral corneal thickness. A clinical study. Arch Ophthalmol. 1968;79(1):28-30.

32. du Toit R, Vega JA, Fonn D, Simpson T. Diurnal variation of corneal sensitivity and thickness. Cornea. 2003;22(3):205-209.

33. Fogagnolo P, Rossetti L, Mazzolani F, Orzalesi N. Circadian variations in central corneal thickness and intraocular pressure in patients with glaucoma. Br J Ophthalmol. 2006;90(1):24-28.

34. Harper CL, Boulton ME, Bennett D, et al. Diurnal variations in human corneal thickness. Br J Ophthalmol. 1996;80(12):1068-1072.

35. Mimura T, Yamagami S, Amano S. Corneal endothelial regeneration and tissue engineering. Prog Retin Eye Res. 2013;35:1-17.
Clinical Interventions in Aging

\section{Publish your work in this journal}

Clinical Interventions in Aging is an international, peer-reviewed journal focusing on evidence-based reports on the value or lack thereof of treatments intended to prevent or delay the onset of maladaptive correlates of aging in human beings. This journal is indexed on PubMed Central, MedLine, the American Chemical Society's 'Chemical Abstracts

\section{Dovepress}

Service' (CAS), Scopus and the Elsevier Bibliographic databases. The manuscript management system is completely online and includes a very quick and fair peer-review system, which is all easy to use. Visit http://www.dovepress.com/testimonials.php to read real quotes from published authors. 